\title{
“Just be careful not to fix 'em to death"
}

\author{
Thoralf M. Sundt, MD
}

From the Division of Cardiac Surgery, Corrigan Minehan Heart Center, Massachusetts General Hospital and Harvard Medical School, Boston, Mass.

Disclosures: Author has nothing to disclose with regard to commercial support.

Received for publication March 20, 2018; accepted for publication March 23, 2018; available ahead of print May 3, 2018.

Address for reprints: Thoralf M. Sundt, MD, Massachusetts General Hospital, 55 Fruit St, Boston, MA 02114 (E-mail: tsundt@mgh.harvard.edu).

J Thorac Cardiovasc Surg 2018;156:14-5

$0022-5223 / \$ 36.00$

Copyright (c) 2018 by The American Association for Thoracic Surgery

https://doi.org/10.1016/j.jtcvs.2018.03.089

I very well remember Jim Cox telling me when I was a resident in St. Louis "just resist the urge to fix 'em to death." I frankly do not remember the case specifically, but it was all about thoughtfully deciding how much to do-and how much not to do. I quote Jim to my residents frequently.

As surgeons, we are programmed to fix things, almost irresistibly so, as if sins of omission are worse than those of commission. Perhaps that is what it attracted us to surgery; faced with a challenging case, we "screw our courage to the sticking post" and give it our best shot. But prophylactic interventions on low-risk patients are distinctly different from high-risk rescue operations whether or not to add a root replacement to an aortic valve replacement differs fundamentally from accepting or declining to operate on that frail soul with prosthetic endocarditis and an essentially certain nonoperative fate. In the former we are electively imposing with certainty for this specific patient an increased short-term risk in hopes of reducing stochastically uncertain risk far in the future. We can debate the levels of risk on each side of the equation, but the fundamental structure of the question is clear.

In this issue of the Journal, the study of Hui and colleagues $^{1}$ aims to help us fill in one side of the equation. Inductive arguments for an aggressive approach to the root are familiar to all, whether biochemical based on matrix metalloproteinase levels or embryologic based on neural crest cell migration. Surely, however, the empirical observations of actual clinical behavior must carry the most weight. The data presented here suggest that, for a nonenlarged root at the time of aortic valve replacement — whether associated with a tricuspid or bicuspid vale - the risk of late sinus dilatation is low and accordingly there is no need for its replacement.

To be sure, there are limitations to the study. During this time interval, far more patients underwent rootreplacement (1660) than root-preserving (406) surgery. Furthermore, one third had some sort of intervention on the noncoronary sinus, and two thirds had aortic stenosis as their functional valve pathology. Therefore, the message is not one of universal root preservation. But for those with

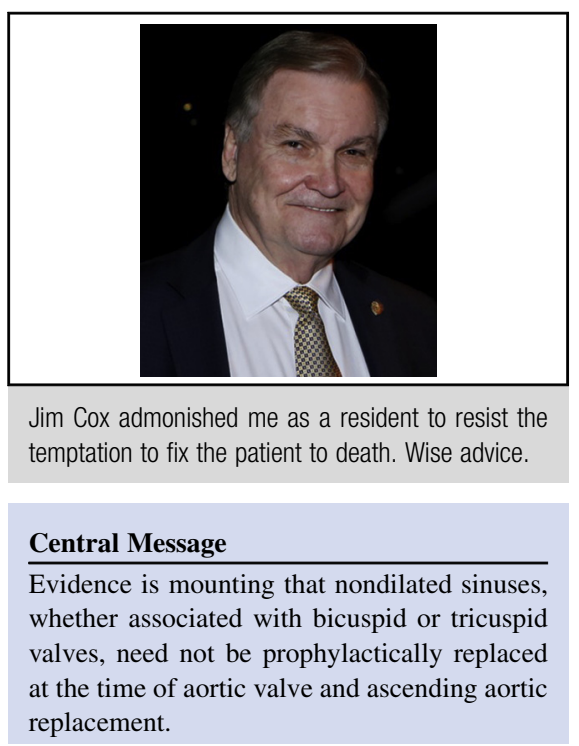

See Article page 5 .

normal root, and importantly accordingly nondisplaced coronary arteries, replacement of the coronary sinuses and coronary reimplantation are not necessary. These are of course the individuals at greatest risk for complications of root surgery. Any surgeon who has not had trouble with a coronary reimplantation-too high or too low, twisted or torn-has not done very many root replacements. It does not happen often, but it can be fatal. Replacement of the noncoronary sinus is much less demanding and in fact is a preference of mine to simplify reoperation if a tissue prosthesis is implanted. It sure makes the secondary graftotomy simpler!

It is no secret that alternate views of this topic have been enthusiastically expressed and have been the grist for many "pro-con" debates. Given these new data in addition to other recent studies, ${ }^{2-5}$ a conservative might be tempted to smugly suggest that "the pendulum is now swinging back." Unfortunately, however, when a pendulum swings back it passes the midline and swings too far the other way as well. None of us want to commit sins of omission, either. Better that the pendulum stops right in the midline, at exactly the correct position in which we do neither too little or too much. Let's fix what needs to be fixed, but not fix 'em to death.

\section{References}

1. Hui SK, Fan C-PS, Christie S, Feindel CM, David TE, Ouzounian M. The aortic root does not dilate over time after replacement of the aortic valve and ascending aorta in patients with bicuspid or tricuspid aortic valves. J Thorac Cardiovasc Surg. 2018;156:5-13.e1. 
2. Park CB, Greason KL, Suri RM, Michelena HI, Schaff HV, Sundt TM. Fate of nonreplaced sinuses of Valsalva in bicuspid aortic valve disease. J Thorac Cardiovasc Surg. 2011;142:278-84.

3. Girdauskas E, Rouman M, Disha K, Dubslaff G, Fey B, Misfeld M, et al. The fate of mild-to-moderate proximal aortic dilatation after isolated aortic valve replacement for bicuspid aortic valve stenosis: a magnetic resonance imaging follow-up study. Eur J Cardiothorac Surg. 2016;49:e80-6; discussion e86-7.
4. Milewski RK, Habertheuer A, Bavaria JE, Siki M, Szeto WY, Krause E, et al. Fate of remnant sinuses of Valsalva in patients with bicuspid and trileaflet valves undergoing aortic valve, ascending aorta, and aortic arch replacement. J Thorac Cardiovasc Surg. 2017;154:421-32.

5. Wang Y, Lin Y, Yin K, Zhu K, Yang Z, Sun Y, et al. Should sinus of Valsalva be preserved in patients with bicuspid aortic valve and aortic dilation? J Thorac Dis. 2017;9:3148-53. 